\title{
Elevated frequencies of leukemic myeloid and plasmacytoid dendritic cells in acute myeloid leukemia with the FLT3 internal tandem duplication
}

\author{
Mareike Rickmann • Juergen Krauter • Kathrin Stamer • Michael Heuser • \\ Gustavo Salguero $\cdot$ Eva Mischak-Weissinger $\cdot$ Arnold Ganser $\cdot$ Renata Stripecke
}

Received: 22 March 2011 / Accepted: 27 March 2011 / Published online: 26 April 2011

(C) The Author(s) 2011. This article is published with open access at Springerlink.com

\begin{abstract}
Some 30\% of acute myeloid leukemia (AML) patients display an internal tandem duplication (ITD) mutation in the FMS-like tyrosine kinase 3 (FLT3) gene. FLT3-ITDs are known to drive hematopoietic stem cells towards FLT3 ligand independent growth, but the effects on dendritic cell (DC) differentiation during leukemogenesis are not clear. We compared the frequency of cells with immunophenotype of myeloid DC (mDC: Lin $^{-}, \mathrm{HLA}-\mathrm{DR}^{+}$, $\left.\mathrm{CD} 11 \mathrm{c}^{+}, \mathrm{CD} 86^{+}\right)$and plasmacytoid DC (pDC: Lin $^{-}$, HLA$\left.\mathrm{DR}^{+}, \mathrm{CD} 123^{+}, \mathrm{CD} 86^{+}\right)$in diagnostic samples of 47 FLT3ITD $^{-}$and 40 FLT3-ITD $^{+}$AML patients. The majority of $\mathrm{ITD}^{+}$AML samples showed high frequencies of mDCs or pDCs, with significantly decreased HLA-DR expression compared with DCs detectable in ITD $^{-}$AML samples. Interestingly, $\mathrm{mDCs}$ and $\mathrm{pDCs}$ sorted out from $\mathrm{ITD}^{+} \mathrm{AML}$ samples contained the ITD insert revealing their leukemic origin and, upon ex vivo culture with cytokines, they acquired DC morphology. Notably, $\mathrm{mDC} / \mathrm{pDCs}$ were detectable concurrently with single lineage $\mathrm{mDCs}$ and pDCs in all $\operatorname{ITD}^{+}$AML $(n=11)$ and $\operatorname{ITD}^{-}$AML $(n=12)$ samples analyzed for mixed lineage DCs ( $\mathrm{Lin}^{-}$, HLA-DR ${ }^{+}$, $\left.\mathrm{CD} 11 \mathrm{c}^{+}, \mathrm{CD} 123^{+}\right) \cdot \mathrm{ITD}^{+}$AML mDCs/pDCs could be only partially activated with $\mathrm{CD} 40 \mathrm{~L}$ and $\mathrm{CpG}$ for production of IFN- $\alpha$, TNF- $\alpha$, and IL- $1 \alpha$, which may affect the anti-
\end{abstract}

M. Rickmann $\cdot$ J. Krauter $\cdot$ K. Stamer $\cdot$ M. Heuser $\cdot$ G. Salguero $\cdot$

E. Mischak-Weissinger $\cdot$ A. Ganser $\cdot$ R. Stripecke

Department of Hematology, Hemostasis, Oncology and Stem Cell

Transplantation, Hannover Medical School (MH),

Hannover, Germany

R. Stripecke $(\bowtie)$

Lymphatic Cell Therapy Laboratory,

Hannover Medical School-OE6860,

Carl-Neuberg Str. 1,

30625 Hannover, Germany

e-mail: stripecke.renata@mh-hannover.de leukemia immune surveillance in the course of disease progression.

Keywords Acute myeloid leukemia $\cdot$ Dendritic cells $\cdot$ Flt3 ITD (FMS like tyrosine kinase internal tandem duplication)

\section{Introduction}

Dendritic cells (DCs) are professional antigen-presenting cells (APCs) derived from bone marrow precursors. DCs internalize and process antigens for presentation to $\mathrm{T}$ and $\mathrm{B}$ cells in the lymphatic tissue for induction of adaptive cellular and humoral responses. There are two major subpopulations of DCs in the human peripheral blood, $\mathrm{CD} 11 \mathrm{c}^{+} \mathrm{CD} 123^{-}$(mDC, also known as myeloid DC or $\mathrm{DC} 1$ ) and $\mathrm{CD} 11 \mathrm{c}^{-} \mathrm{CD} 123^{+} \mathrm{DC}$ (known as plasmacytoid $\mathrm{DC}, \mathrm{pDC}$, or also DC2). DCs occur in very low frequency in the peripheral blood of both humans and mice $(<1 \%)$ [1], and the homeostatic mechanism regulating DC frequency has not been fully elucidated. It is established that DC progenitors require factors such as granulocyte-macrophage colony-stimulating factor (GM-CSF: $\mathrm{mDC}$ ) and FMS-like tyrosine kinase 3 ligand (FL: $\mathrm{mDC}, \mathrm{pDC}$ ) to expand and differentiate $[2,3]$. FL is proposed to be a key regulator of the DC compartment as it is expressed on early hematopoietic stem and progenitor cells, particularly DC precursors $[4,5]$. Therefore, the exposure of myeloid and lymphoid committed precursors to soluble FL can dramatically increase $\mathrm{mDC}$ and $\mathrm{pDC}$ frequencies in mice and humans $[4,6]$.

FLT3, the cognate FL receptor, is a frequent target for mutations in leukemia. An internal tandem duplication (ITD) mutation within FLT3 is found in approximately $30 \%$ of acute myeloid leukemia (AML) cases with normal 
cytogenetics. The leukemic population is commonly monoclonal and its occurrence is linked with a particularly poor prognosis and increased incidence of relapse [2, 7-10]. A hallmark of FLT3-ITD ${ }^{+}$AML blasts is a constitutive activation of the tyrosine kinase, leading to prolonged survival and promoted proliferation of hematopoietic stem/ progenitor cells (independent of FL), as well as a partially blocked differentiation along the granulocytic/monocytic lineages $[2,5,7,11]$. FLT3-ITD seems to be preferentially associated with myelomonocytic and monocytic leukemia (M4, M5) [12]. Although some DC markers have been detected in FLT3-ITD ${ }^{+}$AML cells (HLA-DR, CD123, CD4) [9], the association of FLT3-ITD ${ }^{+}$with abnormal frequencies of $\mathrm{mDCs}$ or $\mathrm{pDCs}$ has not been described previously in humans. Attempts to generate AML-DCs using in vitro culture systems with cytokines have previously indicated that FLT3-ITD would hamper the differentiation of AML blasts towards dendritic cells [13], but these studies did not specifically address the presence of $\mathrm{ITD}^{+}$AML-DCs in the original diagnostic samples. Incidentally, results obtained from murine bone marrow transplantation assays demonstrated that a knock-in of an ITD into murine FLT3 conferred myeloproliferative disease with increment in the frequency of circulating and spleen mDCs $\left(\mathrm{CD} 11 \mathrm{c}^{+}, \mathrm{CD} 86^{+}\right)$[14].

Since the characterization of DC frequencies in clinical $\mathrm{ITD}^{+}$AML samples were not described before, we examined whether the presence of the FLT3-ITD mutation in diagnostic peripheral blood samples obtained from AML patients would affect the occurrence of mDCs and pDCs. Samples obtained from healthy donors and ITD $^{-}$AML patients were used as a comparative parameter. Here, we demonstrate that at leukemia presentation, FLT3ITD $^{+}$AML patients and FLT3-ITD ${ }^{-}$AML patients have a conspicuously high frequency of circulating $\mathrm{mDCs}, \mathrm{pDCs}$, and also mixed lineage mDCs/pDCs. Mixed lineage $\mathrm{mDCs} / \mathrm{pDCs}$ detected in FLT3-ITD ${ }^{+}$AML samples could only be partially activated in vitro to produce inflammatory cytokines.

\section{Materials and methods}

Patient samples

The collection of peripheral blood samples from healthy volunteers $(n=10)$ and AML patients was approved by the local ethics committee of the Hannover Medical School $(\mathrm{MHH})$ and were obtained after an informed consent. A total of 40 FLT3-ITD $^{+}$and 47 FLT3-ITD $^{-}$AML patients were included in the study (Table 1). Due to limitations on the number of viable cells present in diagnostic leukemia samples required for more complex flow cytometry analyses (detection of mixed lineage DCs and analyses of cytokine production), an additional second cohort was included in the study, corresponding to 11 FLT3-ITD ${ }^{+}$ patients and 12 FLT3-ITD $^{-}$patients (Table 1).

\section{Cytogenetics and FLT3-ITD analyses}

Cytogenetic and molecular genetic studies were performed by the German-Austrian Acute Myeloid Leukemia Study Group at Hannover Medical School or at the University of Ulm. Blood diagnostic samples were analyzed for the presence of ITD mutations in the FLT3 gene by polymerase chain reaction as described previously [15]. For FLT3-ITD molecular analyses, DNA was extracted from approximately $5 \times 10^{6}$ cells using Qiagen Blood Mini Columns according to the protocol of the manufacturer. Polymerase chain reaction (PCR) was performed with genomic DNA using primer molecules FLT3-14f-6F 5'-GCA ATT TAG GTA TGA AAG CCA GC-3' and FLT3-E15R 5'-CTT TCA GCA TTT TGA CGG CAA CC. A 5-ng DNA was amplified in a total volume of $50 \mu \mathrm{l}$ containing $50 \mathrm{mM}$ $\mathrm{KCl}, 10 \mathrm{mM}$ Tris- $\mathrm{HCl}, \mathrm{pH} 8.3,1.5 \mathrm{mM} \mathrm{MgCl}{ }_{2}$ and $0.001 \%$ $(w / v)$ gelatine, $200 \mu \mathrm{M}$ dNTPs, primer oligonucleotides (FLT3-E14-6F [5-prime labeled with 6-FAM] and FLT3E5R; $0.5 \mu \mathrm{M}$ each), and 1 unit of AmpliTaq Gold DNA polymerase (Perkin-Elmer, Norwalk, CO, USA). The PCR consisted of an initial incubation step at $95^{\circ} \mathrm{C}$ for $11 \mathrm{~min}$ followed by 27 cycles at $94^{\circ} \mathrm{C}$ for $30 \mathrm{~s}, 57^{\circ} \mathrm{C}$ for $60 \mathrm{~s}$, and $72^{\circ} \mathrm{C}$ for $120 \mathrm{~s}$, and a final elongation step at $94^{\circ} \mathrm{C}$ for $30 \mathrm{~s}$, and $60^{\circ} \mathrm{C}$ for $45 \mathrm{~min}$ in ABI 9700 PCR machines. The PCR products were resolved on a $2 \%$ agarose gels stained with ethidium bromide. DNA of fluorescence-activated cell sorting (FACS)-sorted cells with DC immunophenotype was amplified by PCR and sequencing was performed on an Applied Biosystems 3130 sequencer and analysed with GeneMapper 4.0 (Applied Biosystems, Delaware/US).

Immunophenotypic analyses and sorting of $\mathrm{mDCs}$ and $\mathrm{pDCs}$

Peripheral blood mononuclear cells (PBMCs) obtained from patients and healthy volunteers were isolated by standard density gradient centrifugation using Ficoll (Biocoll separating solution, Greiner, Bio-One, Germany) separation and cryopreserved in 90\% FBS and 10\% DMSO. The mDCs and pDCs were identified using a commercially available kit ("peripheral blood dendritic cell detection by flow cytometry", Becton Dickinson BD, San Jose, CA, USA). The protocol is based on a four color staining. For detection of myeloid DCs, we used lineage cocktail 1 (FITC) containing monoclonal antibodies (mABs) against CD3, CD14, CD16, CD19, CD20, and CD56 as a negative selection, a mAB against CD11c (APC, clone S-HCL-3), a 
Table 1 Patients' characteristics for the first cohort (mDCs or pDCs analyses) and second cohort (mDCs or pDCs or $\mathrm{mDC} / \mathrm{pDC}$ analyses) $(p \leq 0.05)$

\begin{tabular}{|c|c|c|c|c|c|}
\hline & $\begin{array}{l}\text { First cohort } F L T 3 \\
\text { ITD positive }(N=33)\end{array}$ & $\begin{array}{l}\text { First cohort FLT3 } \\
\text { ITD negative }(N=42)\end{array}$ & $p$ value & $\begin{array}{l}\text { Second cohort } F L T 3 \\
\text { ITD positive }(n=11)^{\mathrm{a}}\end{array}$ & $\begin{array}{l}\text { Second cohort FLT3 } \\
\text { ITD negative }(n=12)^{\mathrm{b}}\end{array}$ \\
\hline Age, median (range) years & $62(32-84)$ & $56.5(18-82)$ & 0.17 & $60.38(44-83)$ & $56.8(35-79)$ \\
\hline \multicolumn{6}{|l|}{ Sex $($ no. $/ \%)$} \\
\hline Male & $18(55)$ & $25(60)$ & 0.67 & $6(54)$ & $6(60)$ \\
\hline Female & $15(45)$ & $17(40)$ & & $5(46)$ & $4(40)$ \\
\hline WBC median $\left(\times 10^{9} / \mathrm{L}\right)$ & 95.19 & 65.69 & 0.1 & 67.7 & 63.52 \\
\hline FAB (no./\%) & $N=18$ & $N=21$ & 0.29 & $N=10$ & $N=8$ \\
\hline M0 & $2(11)$ & $2(10)$ & & $1(9)$ & $0(0)$ \\
\hline M1 & $1(6)$ & $5(24)$ & & $2(18)$ & $2(16)$ \\
\hline M2 & $4(22)$ & $3(14)$ & & $1(9)$ & $0(10)$ \\
\hline M3 & $3(17)$ & $0(0)$ & & $0(0)$ & $0(0)$ \\
\hline M4 & $3(17)$ & $5(24)$ & & $3(27)$ & $3(25)$ \\
\hline M5 & $5(27)$ & $6(28)$ & & $5(45)$ & $3(25)$ \\
\hline Not FAB classified & $(15)$ & $(21)$ & & (1) & (4) \\
\hline \multicolumn{6}{|l|}{ Cytogenetics (no./\%) } \\
\hline Favorable & $3(9)$ & $3(7)$ & 0.13 & $0(0)$ & $0(0)$ \\
\hline Intermediate & $26(79)$ & $28(67)$ & & $7(63)$ & $7(58)$ \\
\hline Adverse & $2(6)$ & $10(24)$ & & $2(18)$ & $4(33)$ \\
\hline Missing & $2(6)$ & $1(2)$ & & $2(15)$ & $1(10)$ \\
\hline Probability of relapse (\%) & 15 & 24 & 0.51 & N.A. & N.A. \\
\hline Allo-transplantation (\%) & 21 & 31 & 0.33 & 36 & 33 \\
\hline $\begin{array}{l}\text { Complete remission } \\
\text { to date }(\mathrm{CR})(\text { no./\%) }\end{array}$ & $15(45)$ & $22(54)$ & 0.48 & $4(36)$ & $9(75)$ \\
\hline
\end{tabular}

FAB French-American-British classification, FLT3 FMS-like tyrosine kinase 3, ITD internal tandem duplication, WBC white blood cells, N.A. not applicable

${ }^{\mathrm{a}}$ Four of the patients in this cohort were previously included in FLT3-ITD + cohort 1

${ }^{\mathrm{b}}$ Seven of the patients in this cohort were previously included in FLT3-ITD- cohort 1

mAB against HLA-DR (PerCp, clone L243), and a mAB against CD86 (clone FUN-1) or CD83 (clone HB15e) (both PE). Detection of plasmacytoid DCs was similar, except that instead CD11c, CD123 detection (PE, clone 9F5) was performed. Stained cells were analyzed on a FACSCalibur cytometer using CellQuest software (BD, San Jose, CA, USA). Fifty thousand viable cells gated on the FSC/SSC scatter were negatively selected using the lineage markers. The resulting lin $^{-}$population was analyzed for HLA-DR/CD11c(mDCs) or HLA-DR/CD123- (pDCs) expressing cells. The activation/maturation status of DCs was evaluated by analyses of CD86 and CD83 expression.

Eleven additional $\mathrm{ITD}^{+}$AML samples for which we could obtain higher viable cell numbers were further characterized as mixed lineage mDCs and pDCs upon analyses of $\mathrm{lin}^{-} / \mathrm{HLA}-\mathrm{DR}{ }^{+} / \mathrm{CD} 11 \mathrm{c}^{+} / \mathrm{CD} 123^{+}$cells. Four of the 11 patients were analyzed with an analysis based on $\operatorname{lin}^{-} / \mathrm{HLA}^{-} \mathrm{DR}^{+} / \mathrm{CD}^{+} / \mathrm{CD} 11 \mathrm{c}^{+} / \mathrm{CD} 123^{+}$. The samples were incubated for $2 \mathrm{~h}$ with Golgi Plug (BD, Heidelberg) to inhibit cytokine secretion. Cells were prepared following a BD cytofix/cytoperm protocol for intracellular staining. The cells were harvested on ice, washed, and stained for the expression of cell surface lineage markers (FITC), HLA-DR (V450, BD), CD11c (APC, BD), CD123 (PerCp Cy-5.5, BD), and CD4 (Alexa700, BD). The cells were subsequently stained intracellularly for tumor necrosis factor (TNF)- $\alpha$ (PE-Cy 7) and INF- $\alpha$ (PE-Green A, BD) or IL-1 $\alpha$ (PE-Green A, BD), respectively. After staining, cells were acquired at a minimum of 100,000 events. Five color flow cytometry analysis was performed using an LSR II apparatus. Analyses were made with BD FACS DIVA.

Morphological analyses of thawed/sorted and ex vivo cultured samples

In order to analyze the morphology of cells with $\mathrm{mDC}$ or pDC immunophenotypes, diagnostic samples from six 
$\mathrm{ITD}^{+}$patients were thawed and sorted for $\operatorname{lin}^{-} \mathrm{CD} 11$ $\mathrm{c}^{+} \mathrm{HLA}^{-\mathrm{DR}^{+}}$(mDCs) and $\operatorname{lin}^{-} \mathrm{CD} 123^{+} \mathrm{HLA}^{-\mathrm{DR}^{+}}$(pDCs) on a FACSAria (BD). Cells were analyzed directly after sorting by cytospin, Giemsa staining, and microscopy (Olympus CKX 41) or were further cultivated under DC differentiation/ maturation conditions. ITD ${ }^{+} \mathrm{mDC}$-sorted cells were cultured in 12-well culture plates in an X-vivo medium (Lonza, Basel, Switzerland) in the presence of recombinant human (rh) GM-CSF (20 ng/ $\mu$ l, Cell Genix $\mathrm{GmbH}$, Freiburg, Germany) and recombinant human (rh) interleukin (IL)-4 (20 ng/ $\mu \mathrm{l}$, Cell Genix GmbH, Freiburg, Germany). ITD $^{+}$pDC-sorted cells were cultured in the presence of rhIL-3 $(10 \mathrm{ng} / \mathrm{ml}, \mathrm{R} \& \mathrm{D}$ systems, Cologne, Germany). After 5 to 7 days in culture, $\mathrm{mDCs}$ and $\mathrm{pDCs}$ were stimulated with rhCD40-ligand (CD40L) $(50 \mathrm{ng} / \mathrm{ml}$, R\&D Systems, Cologne, Germany).

\section{Results and discussion}

ITD negative and positive AML samples show elevated frequencies of $\mathrm{mDCs}$ and $\mathrm{pDCs}$

We used a commercially available analytical procedure for quantification of DC subsets in whole blood PBMC. CD3 ${ }^{-}$,
$\mathrm{CD} 14^{-}, \mathrm{CD} 16^{-}, \mathrm{CD}_{19}^{-}, \mathrm{CD} 20^{-}$, and $\mathrm{CD}^{-} 6^{-}$cells were analyzed for expression of HLA-DR/CD11c (mDCs) or HLA-DR/CD123 (pDCs) (Fig. 1a). Activated and matured DCs were further characterized through analyses of CD86 and CD83 expression, respectively [1]. In order to validate the methodology for DC frequency analyses in a healthy control group, we initially analyzed the frequency of mDCs and pDCs in fresh and cryopreserved samples obtained from ten healthy volunteers (Fig. 1b). The fresh samples were analyzed on the day of blood draw, whereas the cryopreserved samples were maintained frozen for at least 1 week prior to analysis. Although the numbers of detectable $\mathrm{mDCs}\left(\mathrm{lin}^{-} / \mathrm{CD} 11 \mathrm{c}^{+} / \mathrm{HLA}-\mathrm{DR}^{+}\right)$and $\mathrm{pDCs}$ $\left(\mathrm{lin}^{-} / \mathrm{CD} 123^{+} / \mathrm{HLA}^{\left.-\mathrm{DR}^{+}\right)}\right.$in cryopreserved samples were lower than fresh samples, the difference was found not to be statistically significant (Fig. 1b). Cryopreserved mDCs of healthy volunteers $(0.82 \pm 0.23 \%$ of PBMC) contained mainly activated $\left(\mathrm{CD} 86^{+}\right)$and mature $\left(\mathrm{CD} 83^{+}\right)$cells. In contrast, in pDCs $(0.44 \pm 0.19$ of PBMC), only approximately half of the cells were activated and mature (Fig. 1c). In contrast to the homogeneous frequencies of the $\mathrm{mDCs}$ (in the range between $0.4 \%$ and $1.2 \%$ ) and pDCs $(0.3-0.8 \%)$ in the PBMC obtained from healthy volunteers, extremely variable frequencies of $\mathrm{mDCs}(0.3-$ $60 \%)$ and pDCs $(0.2-70 \%)$ were observed in $\mathrm{AML}$
Fig. 1 Experimental design and validation of methods. a Schema of the flow cytometry analyses for detection of mDCs and pDCs. b Frequencies of DCs detectable in fresh (black) versus thawed (grey) PBMCs obtained from healthy donors $(n=10)$ do not differ significantly ( $p$ values of $\mathrm{mDCs}$, 0.15 ; pDCs, 0.44.). c Frequencies of cells with $\mathrm{mDC}$ and $\mathrm{pDC}$ immunophenotypes as total cells or with additional expression of the activation marker CD86 and maturation marker CD83 (numbers indicate the average and standard deviation for each analyses; $n=10$ )

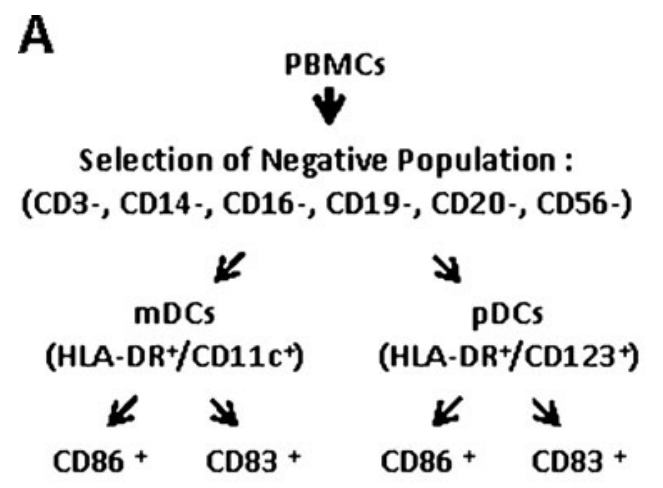

B

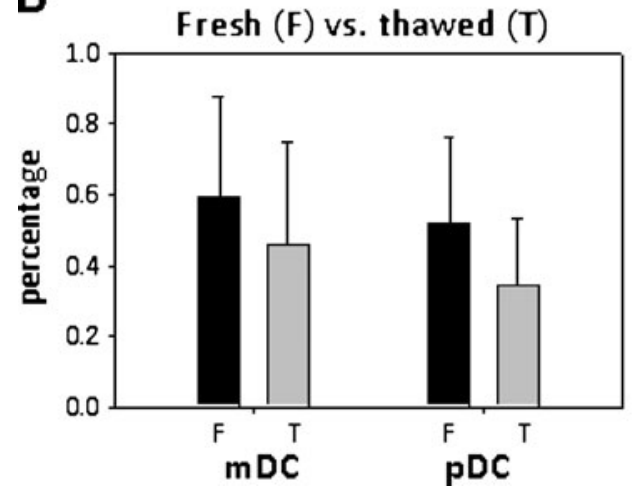

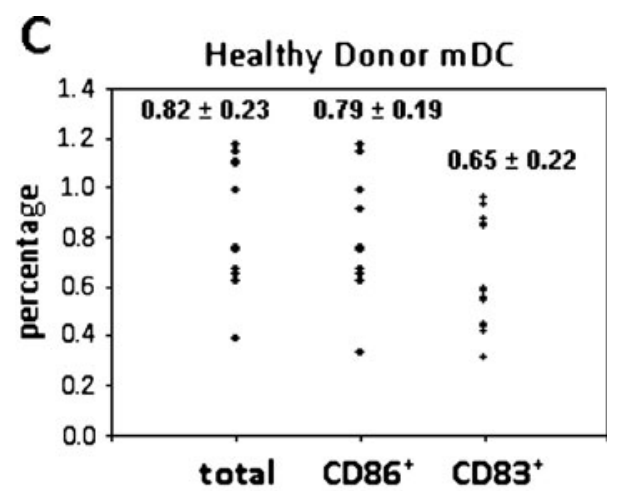

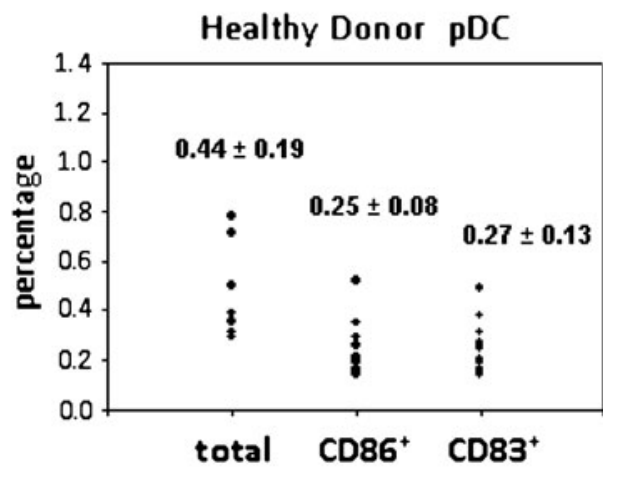


Fig. 2 Flow cytometry analyses of cells with DC immunophenotype in AML diagnostic samples. a Frequencies of mDCs, and $\mathbf{b}$ pDCs detected in FLT3-ITD $^{+}$(upper graphs) and FLT3-ITD ${ }^{-}$AML samples (lower graphs). All analyses indicated significantly higher frequencies of mDCs and $\mathrm{pDCs}$ in ITD $^{+}$and ITD $^{-}$AML samples in comparison with DCs analyses in healthy subjects $(p<0.05)$. The panels on the right side show representative FACS analyses samples with the gating strategy
A mDCs
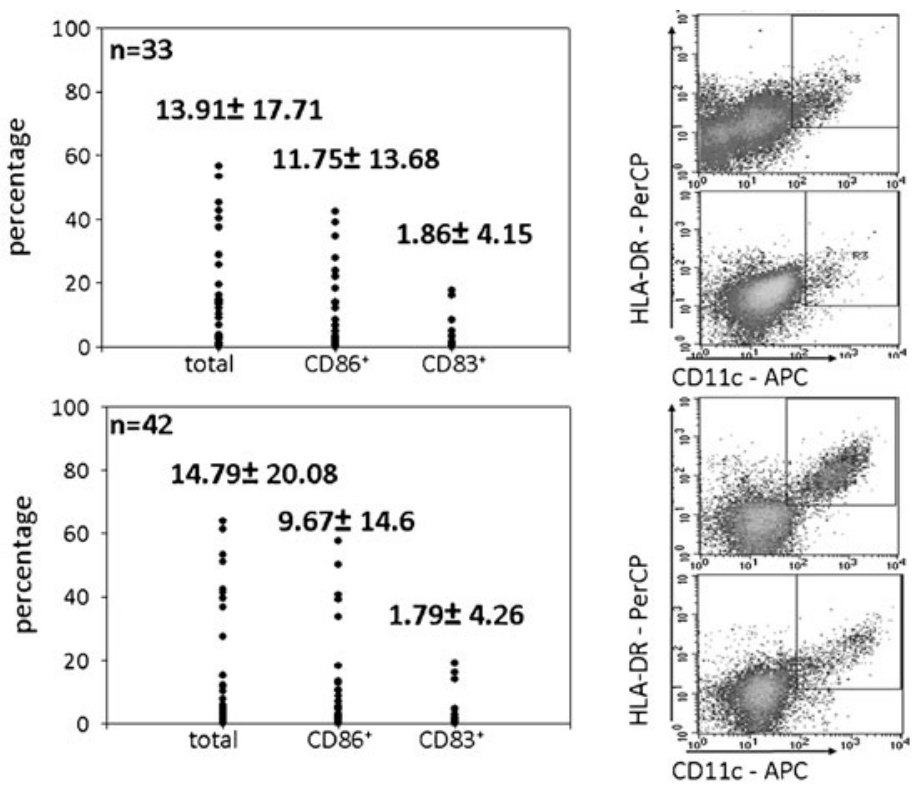

B pDCs

ITD+
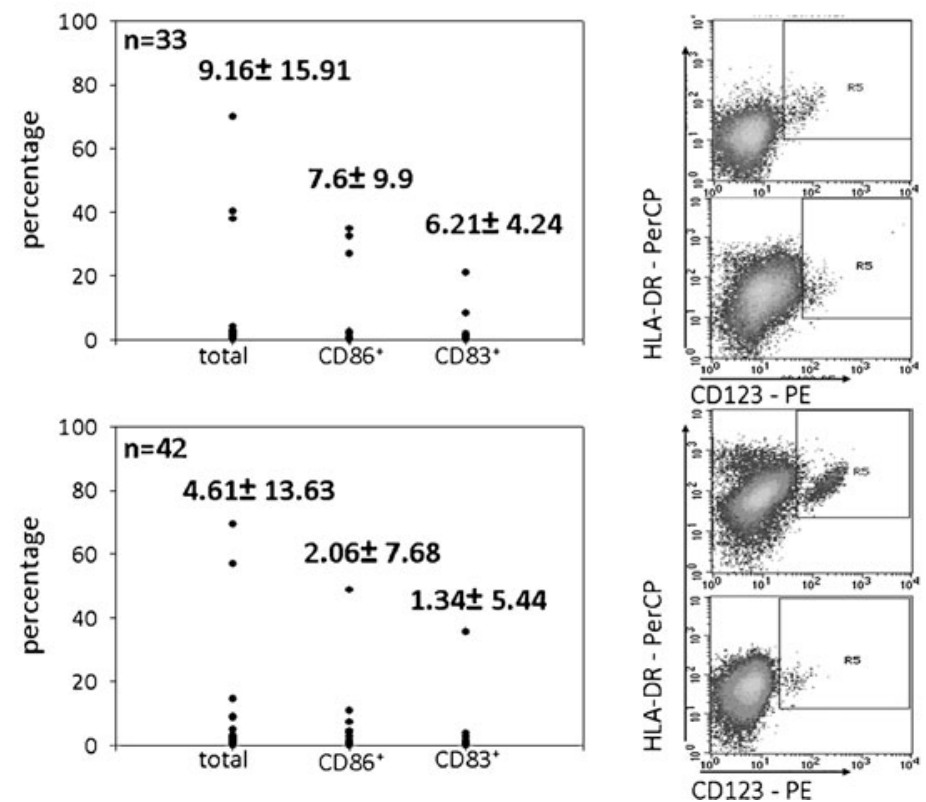

diagnostic samples of both $\mathrm{ITD}^{+}$and $\mathrm{ITD}^{-}$patients (Fig. 2a, b).

Due to the high variability in the frequencies of cells with $\mathrm{mDC}$ immunophenotype, we considered an "aberrant" $\mathrm{mDC}$ frequency for those samples showing $\mathrm{mDC}$ frequencies equal or greater than $10 \%$ of the total viable cells included in the analyses (thus, roughly corresponding to tenfold higher than the normal mDC frequency observed in healthy controls). A remarkable proportion of AML samples had an "aberrant" $\mathrm{mDC}$ frequency $\left(42 \%\right.$ for $\mathrm{ITD}^{+}$and $38 \%$ for $\left.\mathrm{ITD}^{-}\right)$. We did not observe significant differences between the distributions of activated and matured $\mathrm{mDCs}$ in $\mathrm{ITD}^{+}$and $\mathrm{ITD}^{-}$ samples (Fig. 2a). Nevertheless, what was noticeable in these AML samples in comparison to the samples of healthy volunteers, was that a much smaller fraction of the AML-mDCs co-expressed CD86 or CD83, indicating a lower activation and maturation status, respectively.

The average frequency of cells with pDC immunophenotype was also dramatically increased in AML diagnostic samples compared to healthy controls (Fig. 2b). To facilitate the analyses of the highly variable $\mathrm{pDC}$ frequen- 
cies, we considered "aberrant" the samples with equal or greater than $2 \%$ frequency of pDCs (thus, more than fivefold higher than healthy controls). Approximately, $40 \%$ of the samples analyzed in the $\mathrm{ITD}^{+}$group and $26 \%$ in the ITD $^{-}$group were classified as "aberrant", indicating an overall trend for high accumulation of pDCs.

Mohty et al. previously reported the aberrant frequencies of DCs in cryopreserved AML samples [16]. In their work, however, samples were not stratified according to the presence of FLT3-ITD and they used immunoglobulin-like transcript 3 instead of HLA-DR as co-expressed DC marker. In view of our current results, ITD $^{+}$AML samples seem to demonstrate an even more pronounced pattern of aberrant DC frequencies than ITD $^{-}$ AML samples.

ITD negative and positive DCs detected in AML samples show downregulation of HLA-DR

Expression of HLA-DR (corresponding to the major histocompatibility complex II) in DCs detected in AML diagnostic samples was expressed at significantly lower levels than for DCs analyzed in the samples of healthy controls (Fig. 3), a finding that correlates with previous observations regarding the downregulation of HLA-DR in AML samples obtained from $\operatorname{ITD}^{+}$patients $[17,18]$. Notably, within the AML groups, the expression of HLA-DR in DC populations detectable in $\mathrm{ITD}^{+}$AML was significantly lower than in DCs detectable in $\mathrm{ITD}^{-}$ samples (Fig. 3). The profound downregulation of HLADR in ITD $^{+}$DC subsets might be implicated in defective class II antigen presentation leading to dysregulation of these APCs. This could potentially affect presentation of leukemia antigens to $\mathrm{CD} 4^{+} \mathrm{T}$ helper cells, hampering development of a stimulatory cytokine environment for anti-leukemia immune responses.

$\mathrm{mDCs}$ and $\mathrm{pDCs}$ detectable in $\mathrm{ITD}^{+}$AML samples are derived from leukemia and can be driven to further differentiate morphologically with cytokines in vitro

An important observation by Mohty et al. [16], who had previously reported high frequencies of $\mathrm{mDC}$ and $\mathrm{pDC}$ subsets in diagnostic AML samples, was that these cells were likely of leukemic origin since they carried the same translocations as the original leukemia. In order to extend this observation to $\mathrm{ITD}^{+}$leukemia, DCs obtained from three different $\mathrm{ITD}^{+}$AML samples were sorted and examined for the presence of the ITD by PCR. DCs sorted from the ITD ${ }^{+}$AML samples contained the ITD mutation, demonstrating that they originated from leukemic blasts (Fig. 4).

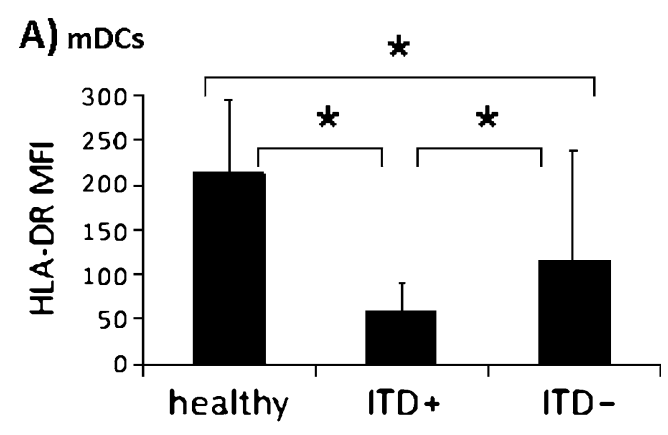

\section{B) pDCs}

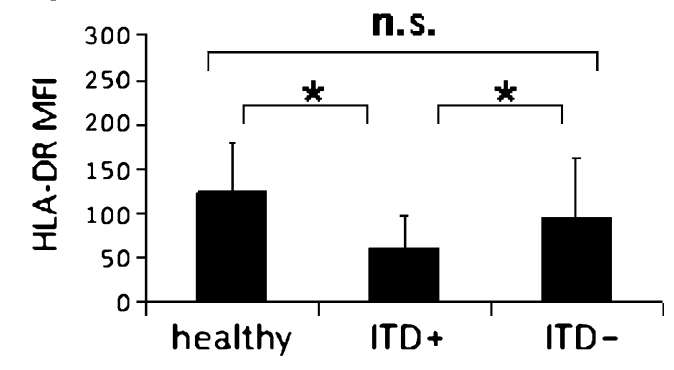

Fig. 3 Flow cytometry analyses of HLA-DR expression in AML cells. a Mean fluorescence intensity (M.F.I.) of HLA-DR expression on $\mathrm{mDCs}$ showing significant (asterisk) differences in the expression level comparing healthy $(n=10), \operatorname{ITD}^{-}(n=42)$ and $\operatorname{ITD}^{+}(n=33)$ PBMC. b M.F.I. of HLA-DR expression on pDCs

These $\mathrm{ITD}^{+}$-sorted DCs were then used for cytospin/ Giemsa preparations and morphological analyses (Fig. 5). Sorted mDCs $\left(\mathrm{Lin}^{-}, \mathrm{HLA}-\mathrm{DR}^{+}, \mathrm{CD} 11 \mathrm{c}^{+}\right)$corresponded to cells with appearance of monocytic blasts with high nuclear-to-cytoplasmic ratio (Fig. 5a). Sorted pDCs demonstrated blast-like morphology with some cells resembling the normal pDC morphology originally described by Siegal et al. [19] and some presenting the "AML-cuplike" description of Kussick et al. [18], who previously described FLT3-ITD ${ }^{+}$blasts with prominent nuclear invagination and decreased HLA-DR expression (Fig. 5b). Sorted ITD ${ }^{+}$DCs that could be cultured ex vivo in the presence of cytokines commonly used for terminal differentiation of mDCs (GM-CSF, IL-4, CD40L) or pDCs (IL-3, CD40L) were analyzed. ITD $^{+}$mDCs maintained in the presence of GM-CSF/IL-4 for 5 days resulted in a population of large cells with dendrites, and upon subsequent 24-h treatment with CD40L, abundant veils on the cell surface typical of mDCs were observed (Fig. 5c). Sorted ITD $^{+}$pDCs cultured in the presence of IL-3 for 5 days resulted in conspicuously large cells, and subsequent $24-\mathrm{h}$ treatment with CD40L resulted in cells with high granularity (Fig. 5d). Put together, these results demonstrated that circulating ITD $^{+}$ DCs have characteristics of leukemic blasts, which upon ex vivo, supra-physiological stimulation with cytokines 
Fig. 4 Sequencing of PCR-ITD mutational insert product from $\mathrm{ITD}^{+}$patients. In addition to the w.t. FLT3 amplification product, the ITD mutational insert is detectable in the original AML patient samples and in the sorted DCs

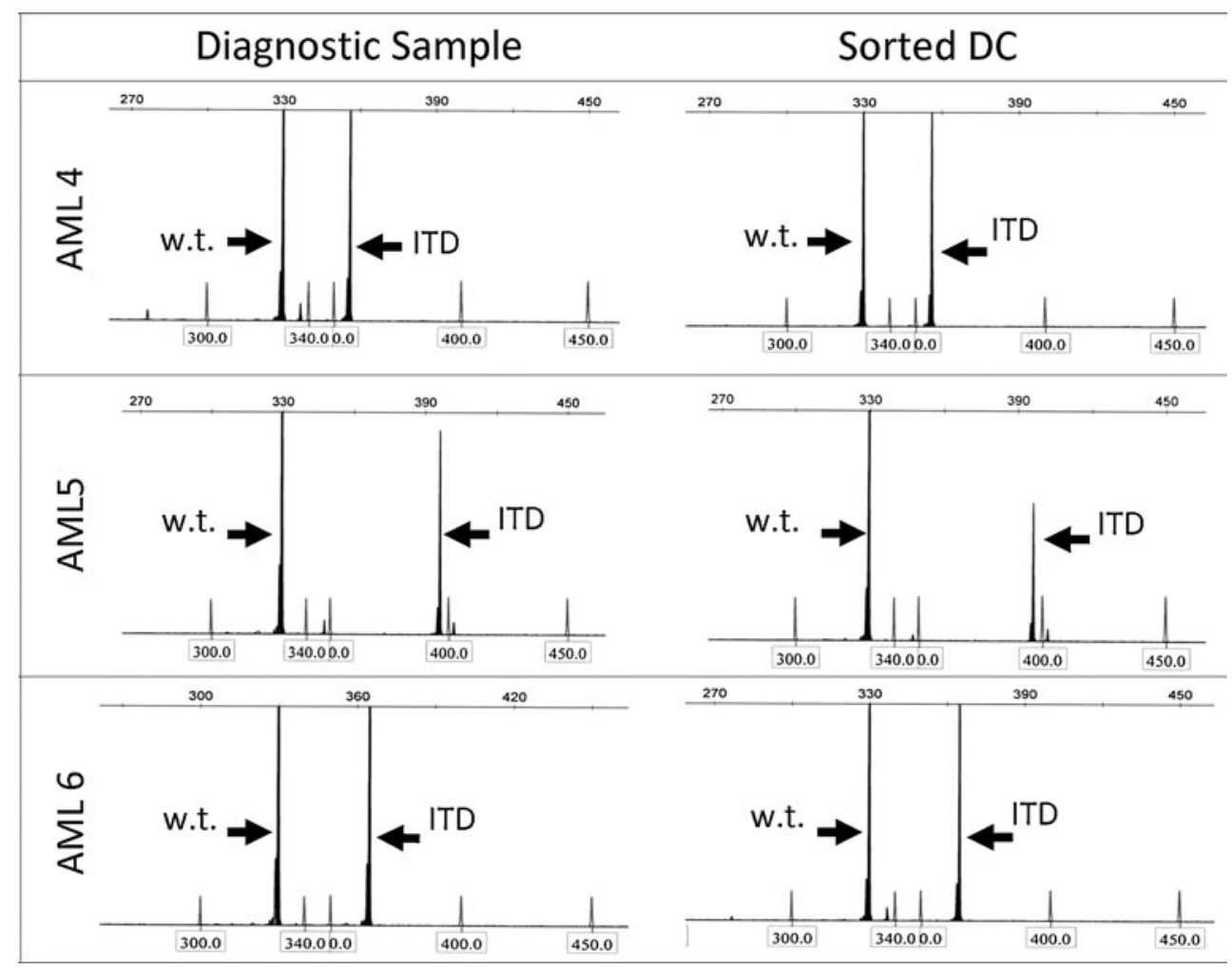

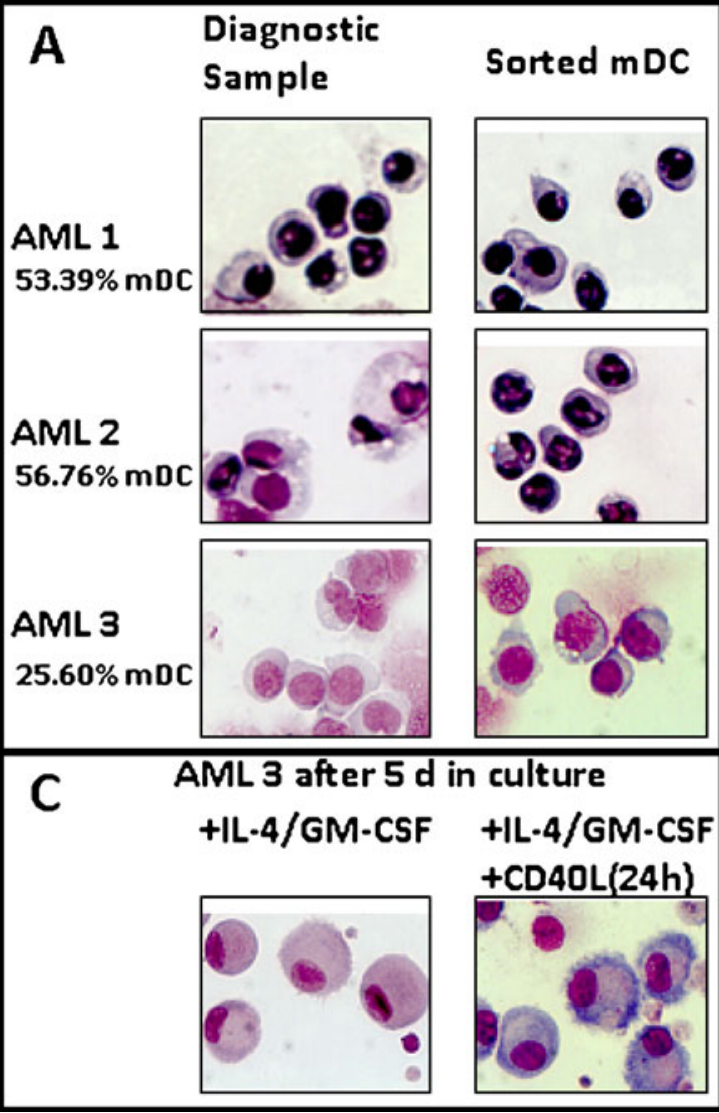

Fig. 5 Morphological analyses of cytospin/Giemsa preparations of FLT3-ITD ${ }^{+}$AML diagnostic samples prior and post-sorting of $\mathrm{mDCs}$ and $\mathrm{pDCs}$. AML samples obtained from three patients and containing high frequencies of mDCs (a) or pDCs (b) before and after sorting

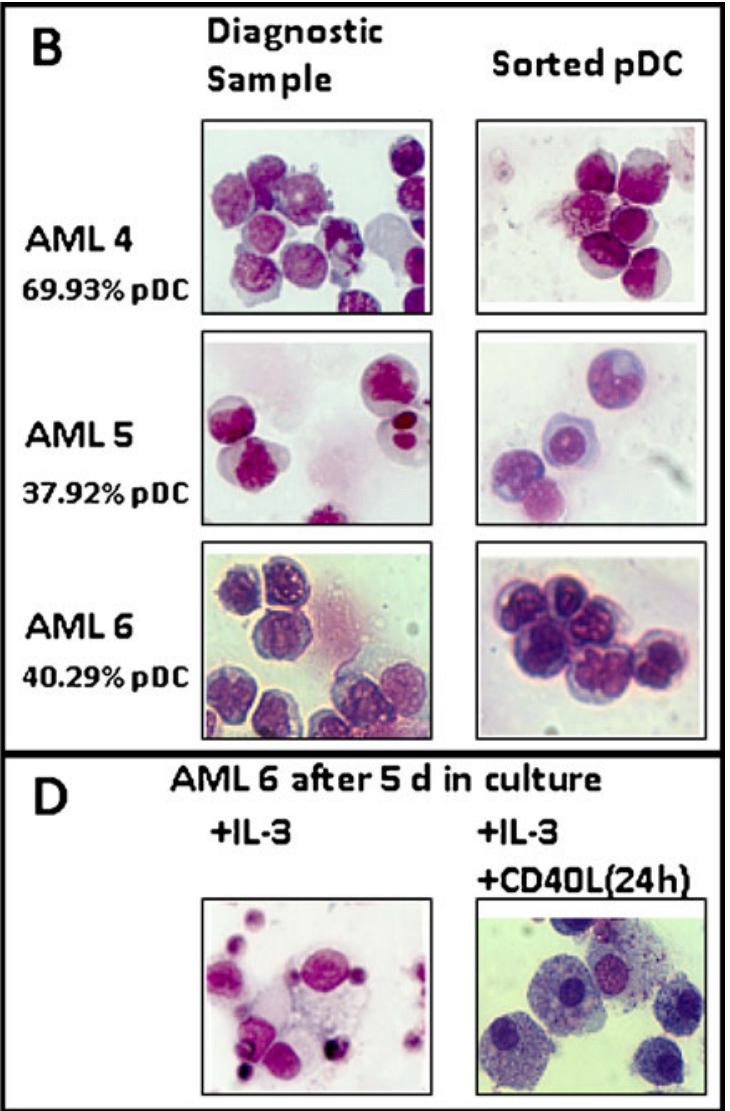

resemble leukemia blasts. $\mathbf{c}$ ITD $^{+}$AML-mDCs after sorting and culture with GM-CSF/IL-4 and maturation with CD40L show cell enlargement and veils. d ITD ${ }^{+}$AML pDCs after sorting and culture with IL-3 and maturation with CD40L show cell enlargement and high granularity 
and maturation factors could drive the cells to acquire more differentiated characteristics.

General occurrence of a mixed lineage population of mDCs $\left(\mathrm{CD}_{11 \mathrm{c}^{+}}\right) / \mathrm{pDCs}\left(\mathrm{CD} 123^{+}\right)$in $\mathrm{ITD}^{+}$and $\mathrm{ITD}^{-}$AML samples

Previous work describing the occurrence of high frequencies of DCs in AML samples considered the $\mathrm{CD} 11 \mathrm{c}^{+} \mathrm{mDC}$ and $\mathrm{CD}_{12} 3^{+} \mathrm{pDC}$ populations as mutually exclusive events [16]. Since we had observed that some AML samples had high frequencies of both $\mathrm{mDCs}$ and $\mathrm{pDCs}$ and since the expression of markers of various hematopoietic lineages is common in leukemogenesis, we evaluated whether mixed $\mathrm{mDCs} / \mathrm{pDCs}$ lineages could also be found in $\mathrm{ITD}^{+}$and/or ITD $^{-}$AML samples. The subsequent flow cytometry analyses consisted in the negative selection of non-DC lineage markers, positive selection of HLA-DR ${ }^{+}$DCs and, within this defined DC population, we analyzed the frequencies of single or double $\mathrm{CD} 11 \mathrm{c}^{+}$and $\mathrm{CD}_{123^{+}}$cells (Fig. 6a). For a subset of ITD $^{+}$patients, we also included the selection of $\mathrm{CD}^{+}$cells for a more stringent characterization of DCs (three representative examples are shown in Fig. 7).

Surprisingly, double positive $\mathrm{mDC} / \mathrm{pDC}$ populations were observed in all $\mathrm{ITD}^{+}$and $\mathrm{ITD}^{-}$AML samples analyzed, and the frequency of double positive DCs

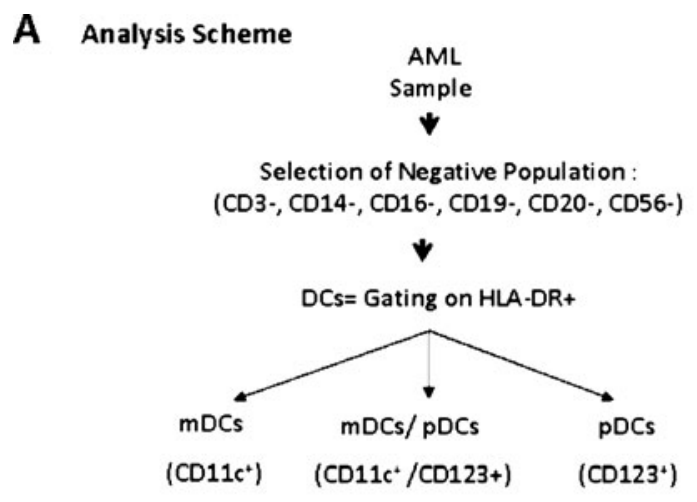

\section{B Frequency of double $\mathrm{mDCs} / \mathrm{pDCs}$ in the DC population}

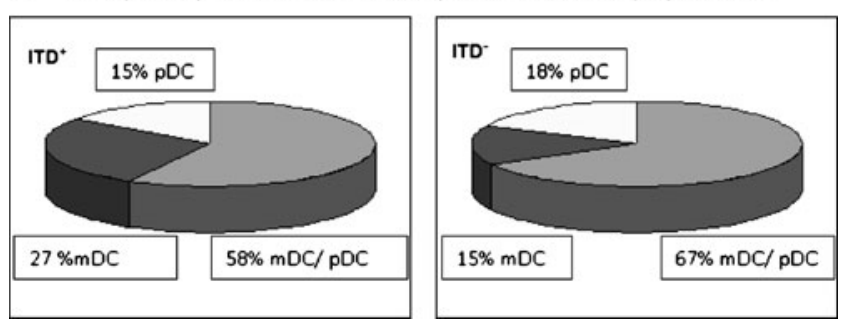

Fig. 6 Immunophenotypic detection of $\mathrm{mDCs} / \mathrm{pDCs}$ ' mixed lineages. a Schematic presentation of flow cytometry analyses. b Average frequency of mixed lineage $\mathrm{mDCs} / \mathrm{pDCs}$, single $\mathrm{mDCs}$ and $\mathrm{pDCs}$ obtained for $\mathrm{ITD}^{+}$and $\mathrm{ITD}^{-}$patients corresponded to an average of $58 \%$ for $\mathrm{ITD}^{+}$and $67 \%$ of $\mathrm{ITD}^{-}$, indicating their preponderance (Fig. 6b, Tables 2 and 3 ). In addition to the double positive $\mathrm{mDCs} / \mathrm{pDCs}$, single $\mathrm{mDCs}$ and $\mathrm{pDCs}$ cell populations were also detectable in the samples in different distributions (Tables 2 and $3 \mathrm{~A}-\mathrm{C}$ ). Of note, $\mathrm{CD} 11 \mathrm{c}^{+} / \mathrm{CD} 123^{+}$cells have recently been described as early precursors of myelocytic DCs derived from $\mathrm{CD} 34^{+}$progenitors [2022]. In fact, $\mathrm{CD} 123$ is the IL-3 receptor (IL-3R) alpha chain, which is a well-established stem cell marker in healthy and leukemic $\mathrm{CD} 34^{+}$stem cells, and is known to be downregulated only late in myeloid differentiation.[2325]. IL-3R/ CD123 expression in $\mathrm{ITD}^{+}$AML blasts has been described as a frequent event $[26,27]$, which here seems to be associated with the accumulation of DC precursors that are not terminally differentiated towards $\mathrm{mDC}$ or $\mathrm{pDC}$. Of note, in this study, we also observed that a subset of ITD $^{+}$AML samples showed a significantly higher expression of CD123 when compared with ITD $^{-}$ AML samples (data not shown).

Analogous to our findings, Ma et al. [28] have also demonstrated clonal involvement in circulating myeloid and lymphoid precursors of dendritic cells in peripheral blood of patients with myelodysplastic syndromes. Altogether, these observations provide evidence that $\mathrm{ITD}^{+}$and also $\mathrm{ITD}^{-}$leukemic or progenitor stem cells differentiate towards common $\mathrm{CD} 11 \mathrm{c}^{+} / \mathrm{CD} 123^{+} \mathrm{mDC} / \mathrm{pDC}$ precursors which are accumulated prior to subsequent split between differentiated $\mathrm{mDCs}$ and $\mathrm{pDCs}$.

Stimulation of $\mathrm{mDCs} / \mathrm{pDCs}$ with $\mathrm{CD} 40 \mathrm{~L}$ or $\mathrm{CpG}$ results into partial activation of the cells for production of inflammatory cytokines

$\mathrm{ITD}^{+}$AML samples were further analyzed for $\mathrm{mDC} / \mathrm{pDC}$ frequencies based on detection of the surface markers $\operatorname{Lin}^{-} /$ HLA-DR ${ }^{+} / \mathrm{CD}^{+}$. Using these more stringent analyses, 5.2$20.5 \%$ of the DCs present in the ITD $^{+}$AML samples corresponded to $\mathrm{mDC} / \mathrm{pDC}$ (Fig. 7a).

In order to correlate the immunophenotypic characteristics of the $\mathrm{mDC} / \mathrm{pDC}$ mixed lineage population with $\mathrm{DC}$ function, we performed intracellular staining of inflammatory cytokines [interferon (IFN)- $\alpha$, TNF- $\alpha$, IL- $1 \alpha$ ] after stimulation of the AML blasts with CD40L or $\mathrm{CpG}$ (Fig. 7b). We used healthy donors as controls for these analyses, which confirmed upregulation of IFN- $\alpha$ production by pDCs after $\mathrm{CpG}$ stimulation (Fig. 7). IFN- $\alpha$ and IL$1 \alpha$ were detectable in all $\mathrm{mDC} / \mathrm{pDC}$ populations, but their regulation through $\mathrm{CpG}$ and $\mathrm{CD} 40 \mathrm{~L}$ was extremely variable. Production of TNF- $\alpha$ by $\mathrm{mDCs} / \mathrm{pDCs}$ was hardly detectable in comparison to healthy $\mathrm{mDCs}$ and $\mathrm{pDCs}$ 
A

A Total DCs (\% of total PBMC)

6

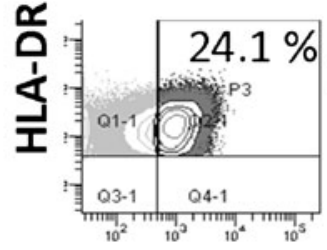

CD4

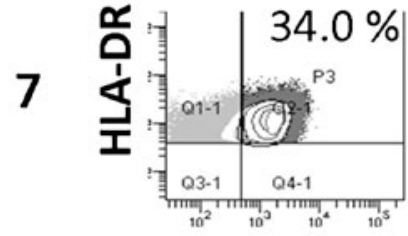

CD4

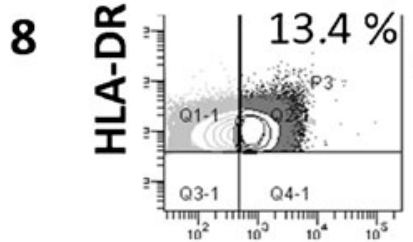

CD4

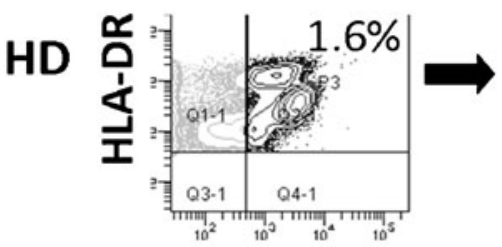

CD4
$\mathrm{mDC} / \mathrm{pDCs}$

(\% of total

PBMC)

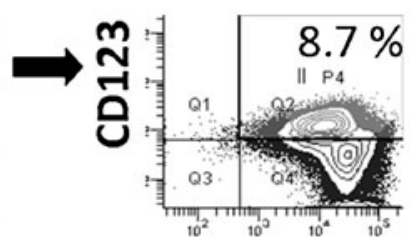

CD11c

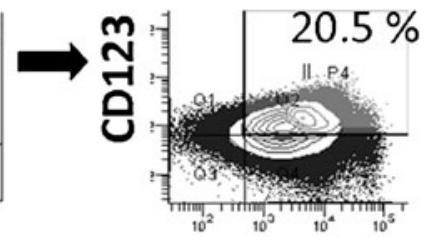

CD11c

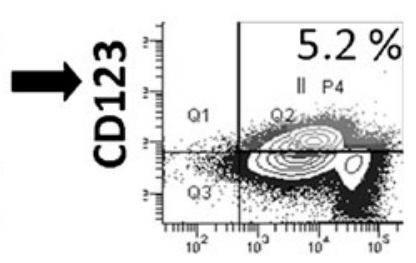

CD11C

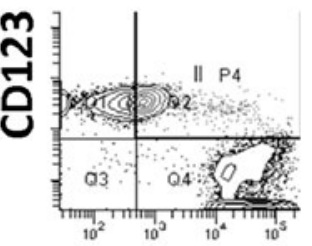

CD11c
B Frequency of $\mathrm{mDC} / \mathrm{pDCs}$

expressing cytokines
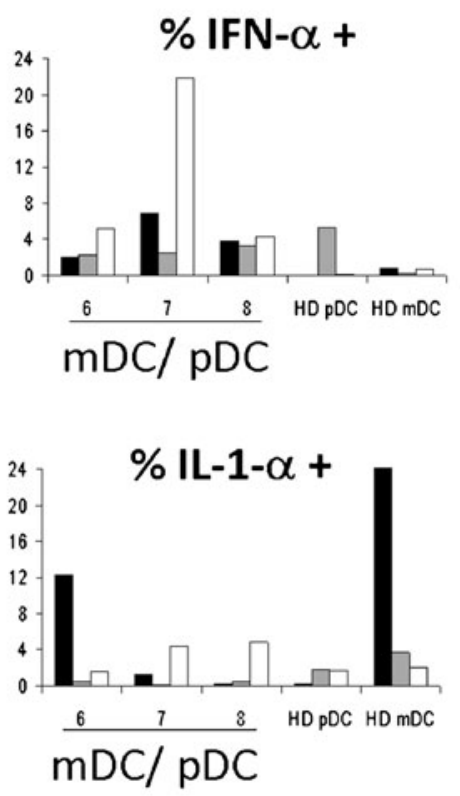

$\%$ TNF- $\alpha+$

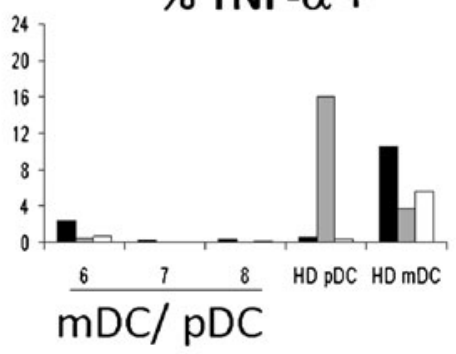

- CD40L

\section{Control}

Fig. 7 Functional analyses of double positive CD11c/CD123 mDCs/pDCs in ITD ${ }^{+}$AML samples of three patients. a Gating approach for detection of $\mathrm{mDCs} / \mathrm{pDCs}$. b Frequency of $\mathrm{mDC} / \mathrm{pDCs}$ with detectable intracellular cytokines after stimulation with $\mathrm{CD} 40 \mathrm{~L}$ or $\mathrm{CpG}$

(Fig. 7). Thus, these functional analyses indicated a deregulated baseline cytokine production and stimulatory responses in $\mathrm{mDCs} / \mathrm{pDCs}$.

Based on long-standing clinical expertise that graft versus leukemia (GVL) effect is an immunologic factor positively influencing leukemia eradication, immunotherapeutic approaches to enhance GVL have been sought. During past years, several groups have pointed to the fact that AML cells can express antigens and can be "corrected" as antigen-presenting cells through cytokine stimulation leading to their terminal differentiation [29]. This approach was however not shown practical for $\mathrm{ITD}^{+}$AML cultures maintained in vitro, which failed to generate $\mathrm{ITD}^{+} \mathrm{AML}-$
DCs in the presence of GM-CSF, IL-4, and TNF- $\alpha$ [13]. In our work, we did obtain a partial correction of the DC morphology and cytokine production, but this was mainly noticeable in the presence of $\mathrm{CD} 40 \mathrm{~L}$ or $\mathrm{CpG}$, which drive terminal maturation of DCs.

In summary, our work demonstrates that both $\mathrm{ITD}^{+}$ and ITD $^{-}$AML samples contain a high proportion of cells with DC progenitor characteristics, hindered in terminal differentiation, partially blocked for maturation, and with deregulated cytokine production characteristics. Thus, our study indicates immunosuppressive mechanisms of an immature $\mathrm{mDC} / \mathrm{pDC}$ leukemic lineage, which might be operative during leukemogenesis and can potentially 
Table 2 Frequency of double positive $\mathrm{mDCs} / \mathrm{pDCs}$ and single mDCs and $\mathrm{pDCs}$ in $11 \mathrm{ITD}^{+}$AML samples

\begin{tabular}{|c|c|c|c|c|c|c|}
\hline AML sample & WBC & FAB & $\% \mathrm{DCs}$ in $\mathrm{PBMC}$ & $\% \mathrm{mDC} / \mathrm{pDC}$ in $\mathrm{DCs}$ & $\% \mathrm{mDC}$ in $\mathrm{DCs}$ & $\% \mathrm{pDC}$ in $\mathrm{DCs}$ \\
\hline \multicolumn{7}{|c|}{ A: High $\mathrm{mDC} / \mathrm{pDC}$ and high $\mathrm{mDC}$ frequencies } \\
\hline 5 & 6.3 & M4 & 23.28 & 79.30 & 18.17 & 2.53 \\
\hline 6 & 56.2 & M5a & 39.2 & 34.95 & 64.79 & 0.25 \\
\hline 7 & 30.3 & $\mathrm{M} 4 / 5$ & 34.7 & 64.54 & 30.84 & 4.61 \\
\hline 8 & 216 & M0 & 34.1 & 39.00 & 60.41 & 0.59 \\
\hline 9 & 107 & M5a & 39.1 & 69.80 & 29.92 & 0.25 \\
\hline 10 & 1.5 & M1 & 3.57 & 27.74 & 60.50 & 11.76 \\
\hline \multicolumn{7}{|c|}{ B: High $\mathrm{mDC} / \mathrm{pDC}$ and high $\mathrm{pDC}$ frequencies } \\
\hline 1 & 69.9 & M2 & 39.04 & 35.00 & 0.48 & 64.52 \\
\hline 2 & 46.3 & M5 & 52.02 & 64.28 & 6.62 & 29.10 \\
\hline 11 & 65.5 & M5 & 11.00 & 73.09 & 8.09 & 18.82 \\
\hline 4 & 79.0 & N.A. & 11.55 & 55.16 & 10.32 & 34.52 \\
\hline \multicolumn{7}{|c|}{$\mathrm{C}$ : High $\mathrm{mDC} / \mathrm{pDC}$ and low $\mathrm{mDCs}$ or $\mathrm{pDCs}$} \\
\hline 3 & 66.7 & M5 & 45.97 & 90.12 & 5.21 & 4.67 \\
\hline
\end{tabular}

Despite the fact that $\mathrm{mDCs} / \mathrm{pDCs}$ were observed in all AML samples, most of the samples showed high frequency of mDCs (A), and some samples showed also high frequencies of pDCs (B) or comparable frequencies of mDCs and pDCs (C)

$A M L$ acute myeloid leukemia, FAB French-American-British classification, FLT3 FMS-like tyrosine kinase 3, ITD internal tandem duplication, $W B C$ white blood cells, N.A. not applicable, $P B M C$ peripheral blood mononuclear cell, $D C s$ dendritic cells, $p D C$ plasmacytoid dendritic cell, $m D C$ myeloid dendritic cell

promote anergy induction, tolerance, and ultimately immune escape of leukemia cells.

These results suggest that by hindering the "AML-DC" differentiation and maturation, the occurrence of FLT3-ITD can potentially undermine anti-leukemia immune responses, which calls for more effective adjuvant immunotherapeutic strategies in $\mathrm{ITD}^{+}$leukemia in order to rebound the immune regeneration for ultimate leukemia elimination.

Table 3 Frequency of double positive mDCs/pDCs and single mDCs and pDCs in 12 ITD $^{-}$AML samples

\begin{tabular}{|c|c|c|c|c|c|c|}
\hline AML sample & WBC & FAB & $\% \mathrm{DCs}$ in $\mathrm{PBMC}$ & $\% \mathrm{mDC} / \mathrm{pDC}$ in $\mathrm{DCs}$ & $\% \mathrm{mDC}$ in $\mathrm{DCs}$ & $\% \mathrm{pDC}$ in $\mathrm{DCs}$ \\
\hline \multicolumn{7}{|c|}{ A: High $\mathrm{mDC} / \mathrm{pDC}$ and high $\mathrm{mDC}$ frequencies } \\
\hline 1 & 4.7 & M1 & 58.26 & 36.09 & 57.57 & 6.32 \\
\hline 2 & 182 & N.A. & 9.9 & 87.36 & 10.20 & 2.41 \\
\hline 3 & 76 & M4 & 9.15 & 59.22 & 34.09 & 6.67 \\
\hline \multicolumn{7}{|c|}{ B: High $\mathrm{mDC} / \mathrm{pDC}$ and high $\mathrm{pDC}$ frequencies } \\
\hline 4 & 5.2 & N.A. & 8.11 & 81.37 & 3.33 & 15.29 \\
\hline 5 & 34 & M5b & 53.71 & 71.37 & 0.36 & 28.23 \\
\hline 6 & 6.8 & M4 & 27.44 & 58.71 & 1.75 & 39.54 \\
\hline 7 & 129.5 & N.A. & 52.79 & 61.53 & 1.52 & 36.94 \\
\hline \multicolumn{7}{|c|}{$\mathrm{C}$ : High $\mathrm{mDC} / \mathrm{pDC}$ and high $\mathrm{mDCs}$ or $\mathrm{pDCs}$} \\
\hline 8 & 0.7 & M4eo & 23.97 & 60.52 & 18.22 & 21.23 \\
\hline 9 & 69 & N.A. & 31.8 & 62.33 & 18.21 & 19.47 \\
\hline 10 & 18.4 & M5 & 21.97 & 61.63 & 15.66 & 22.70 \\
\hline 11 & 23.2 & M1 & 8.08 & 77.60 & 13.24 & 9.16 \\
\hline 12 & 115.7 & M5 & 1.57 & 82.17 & 7.01 & 10.83 \\
\hline
\end{tabular}

The samples varied relative to the majority of $\mathrm{mDCs}(\mathrm{A}), \mathrm{pDCs}(\mathrm{B})$, but for most of the cases comparable frequencies of mDCs and pDCs were observed (C)

$A M L$ acute myeloid leukemia, $F A B$ French-American-British classification, $W B C$ white blood cells, N.A. not applicable, $D C s$ dendritic cells, $P B M C$ peripheral blood mononuclear cell, $p D C$ plasmacytoid dendritic cell, $m D C$ myeloid dendritic cell 
Acknowledgments M.R. designed and performed experiments, analyzed data, and wrote the manuscript; J.K. and A.G. provided AML samples and clinical data and assisted in the characterization of the FLT3-ITD insert; K.S. designed and performed experiments; M.H. performed the statistical analyses; G.S. and E.M.W. analyzed data; and R.S. designed experiments, analyzed data, corrected and completed the manuscript. We are grateful to Dr. Carsten Wiethe for exceptional technical support regarding flow cytometry analyses. We thank members of the Stripecke laboratory for their contributions to the completion of this work. We also thank the MHH sorting facility staff and the clinicians, nurses, and technicians in the Department of Hematology for their professional support. Use of the LSR II flow cytometer was made possible through SFB-738 and technical support of Artur Wilms. The authors gratefully acknowledge Dr. Christopher Baum and Dr. Michael Morgan for critical reading of the manuscript. This work was supported by a collaborative research grant from the Jose Carreras Foundation (to R.S.) and a grant of the German Research Council (DFG/ SFB738 to R.S. and A.G.). R.S. is further supported by the DFG Excellence Cluster Rebirth in Regenerative Medicine and by the Deutsche Krebshilfe. M.R. was supported by a MHH-HBRS/Strucmed fellowship.

Open Access This article is distributed under the terms of the Creative Commons Attribution Noncommercial License which permits any noncommercial use, distribution, and reproduction in any medium, provided the original author(s) and source are credited.

\section{References}

1. Rovati B, Mariucci S, Manzoni M, Bencardino K, Danova M (2008) Flow cytometric detection of circulating dendritic cells in healthy subjects. Eur J Histochem 52(1):45-52

2. Li L, Piloto O, Kim KT, Ye Z, Nguyen HB, Yu X, Levis M, Cheng L, Small D (2007) FLT3/ITD expression increases expansion, survival and entry into cell cycle of human haematopoietic stem/progenitor cells. $\mathrm{Br}$ J Haematol 137 (1):64-75

3. Naik SH (2008) Demystifying the development of dendritic cell subtypes, a little. Immunol Cell Biol 86(5):439-452

4. Karsunky H, Merad M, Cozzio A, Weissman IL, Manz MG (2003) Flt3 ligand regulates dendritic cell development from Flt3+ lymphoid and myeloid-committed progenitors to Flt3+ dendritic cells in vivo. J Exp Med 198(2):305-313

5. Kelly LM, Liu Q, Kutok JL, Williams IR, Boulton CL, Gilliland DG (2002) FLT3 internal tandem duplication mutations associated with human acute myeloid leukemias induce myeloproliferative disease in a murine bone marrow transplant model. Blood 99 (1):310-318

6. Maraskovsky E, Daro E, Roux E, Teepe M, Maliszewski CR, Hoek J, Caron D, Lebsack ME, McKenna HJ (2000) In vivo generation of human dendritic cell subsets by Flt3 ligand. Blood 96(3):878-884

7. Bruserud O, Hovland R, Wergeland L, Huang TS, Gjertsen BT (2003) Flt3-mediated signaling in human acute myelogenous leukemia (AML) blasts: a functional characterization of Flt3ligand effects in AML cell populations with and without genetic Flt3 abnormalities. Haematologica 88(4):416-428

8. Gilliland DG, Griffin JD (2002) Role of FLT3 in leukemia. Curr Opin Hematol 9(4):274-281

9. Munoz L, Aventin A, Villamor N, Junca J, Acebedo G, Domingo A, Rozman M, Torres JP, Tormo M, Nomdedeu JF (2003) Immunophenotypic findings in acute myeloid leukemia with FLT3 internal tandem duplication. Haematologica 88 (6):637-645
10. Schlenk RF, Dohner K, Krauter J, Frohling S, Corbacioglu A, Bullinger L, Habdank M, Spath D, Morgan M, Benner A, Schlegelberger B, Heil G, Ganser A, Dohner H (2008) Mutations and treatment outcome in cytogenetically normal acute myeloid leukemia. N Engl J Med 358(18):1909-1918

11. Zheng R, Friedman AD, Small D (2002) Targeted inhibition of FLT3 overcomes the block to myeloid differentiation in 32Dcl3 cells caused by expression of FLT3/ITD mutations. Blood 100 (12):4154-4161

12. Thiede C, Steudel C, Mohr B, Schaich M, Schakel U, Platzbecker U, Wermke M, Bornhauser M, Ritter M, Neubauer A, Ehninger G, Illmer T (2002) Analysis of FLT3-activating mutations in 979 patients with acute myelogenous leukemia: association with FAB subtypes and identification of subgroups with poor prognosis. Blood 99(12):4326-4335

13. Houtenbos I, Westers TM, Hess CJ, Waisfisz Q, Ossenkoppele GJ, van de Loosdrecht AA (2006) Flt-3 internal tandem duplication hampers differentiation of AML blasts towards leukemic dendritic cells. Leukemia 20(10):1892-1895

14. Li L, Piloto O, Nguyen HB, Greenberg K, Takamiya K, Racke F, Huso D, Small D (2008) Knock-in of an internal tandem duplication mutation into murine FLT3 confers myeloproliferative disease in a mouse model. Blood 111(7):3849-3858

15. Frohling S, Schlenk RF, Breitruck J, Benner A, Kreitmeier S, Tobis K, Dohner H, Dohner K (2002) Prognostic significance of activating FLT3 mutations in younger adults (16 to 60 years) with acute myeloid leukemia and normal cytogenetics: a study of the AML Study Group Ulm. Blood 100 (13):4372-4380

16. Mohty M, Jarrossay D, Lafage-Pochitaloff M, Zandotti C, Briere F, de Lamballeri XN, Isnardon D, Sainty D, Olive D, Gaugler B (2001) Circulating blood dendritic cells from myeloid leukemia patients display quantitative and cytogenetic abnormalities as well as functional impairment. Blood 98 (13):3750-3756

17. Syampurnawati M, Tatsumi E, Furuta K, Takenokuchi $M$, Nakamachi Y, Kawano S, Kumagai S, Saigo K, Matsui T, Takahashi T, Nagai K, Yabe H, Kondo S, Hayashi Y (2007) HLA-DR-negative AML (M1 and M2): FLT3 mutations (ITD and D835) and cell-surface antigen expression. Leuk Res 31(7):921929

18. Kussick SJ, Stirewalt DL, Yi HS, Sheets KM, PogosovaAgadjanyan E, Braswell S, Norwood TH, Radich JP, Wood BL (2004) A distinctive nuclear morphology in acute myeloid leukemia is strongly associated with loss of HLA-DR expression and FLT3 internal tandem duplication. Leukemia 18(10):15911598

19. Siegal FP, Kadowaki N, Shodell M, Fitzgerald-Bocarsly PA, Shah K, Ho S, Antonenko S, Liu YJ (1999) The nature of the principal type 1 interferon-producing cells in human blood. Science 284 (5421):1835-1837

20. Ebner S, Hofer S, Nguyen VA, Furhapter C, Herold M, Fritsch P, Heufler C, Romani N (2002) A novel role for IL-3: human monocytes cultured in the presence of IL- 3 and IL- 4 differentiate into dendritic cells that produce less IL-12 and shift Th cell responses toward a Th2 cytokine pattern. J Immunol 168 (12):6199-6207

21. Shi J, Wang M, Wan Y, Ikeda K (2009) The biological characteristics of peripheral blood CD123+ myeloid dendritic cell. Xi Bao Yu Fen Zi Mian Yi Xue Za Zhi 25(3):204-207

22. Ward KA, Stewart LA, Schwarer AP (2006) CD34+-derived $\mathrm{CD} 11 \mathrm{c}++$ + BDCA- $1+$ + CD123+ + DC: expansion of a phenotypically undescribed myeloid $\mathrm{DC} 1$ population for use in adoptive immunotherapy. Cytotherapy 8(2):130-140

23. Sato N, Caux C, Kitamura T, Watanabe Y, Arai K, Banchereau J, Miyajima A (1993) Expression and factor-dependent modulation 
of the interleukin-3 receptor subunits on human hematopoietic cells. Blood 82(3):752-761

24. Munoz L, Nomdedeu JF, Lopez O, Carnicer MJ, Bellido M, Aventin A, Brunet S, Sierra J (2001) Interleukin-3 receptor alpha chain (CD123) is widely expressed in hematologic malignancies. Haematologica 86(12):1261-1269

25. Jordan CT, Upchurch D, Szilvassy SJ, Guzman ML, Howard DS, Pettigrew AL, Meyerrose T, Rossi R, Grimes B, Rizzieri DA, Luger SM, Phillips GL (2000) The interleukin-3 receptor alpha chain is a unique marker for human acute myelogenous leukemia stem cells. Leukemia 14(10):1777-1784

26. Riccioni R, Diverio D, Riti V, Buffolino S, Mariani G, Boe A, Cedrone M, Ottone T, Foa R, Testa U (2009) Interleukin (IL)-3/ granulocyte macrophage-colony stimulating factor/IL-5 receptor alpha and beta chains are preferentially expressed in acute myeloid leukaemias with mutated FMS-related tyrosine kinase 3 receptor. Br J Haematol 144(3):376-387

27. Sell S (2005) Leukemia: stem cells, maturation arrest, and differentiation therapy. Stem Cell Rev 1(3):197-205

28. Ma L, Delforge M, van Duppen V, Verhoef G, Emanuel B, Boogaerts M, Hagemeijer A, Vandenberghe P (2004) Circulating myeloid and lymphoid precursor dendritic cells are clonally involved in myelodysplastic syndromes. Leukemia 18(9):14511456

29. Stripecke R, Levine AM, Pullarkat V, Cardoso AA (2002) Immunotherapy with acute leukemia cells modified into antigenpresenting cells: ex vivo culture and gene transfer methods. Leukemia 16(10):1974-1983 